\title{
THE ATTRIBUTES OF PERSONAL TAXPAYER'S COMPLIANCE IN INDONESIA
}

\author{
Mohammad Syafriel $^{1}$ \\ ${ }^{1}$ Accounting Program, Indocakti Institute of Economics Science, Jl. Ijen Besar 90-92, Malang, 65112, Indonesia \\ Corresponding e-mail: mohammad.syafr1el@gmail.com
}

\begin{abstract}
The aim of this study is to confirm the attributes of personal taxpayer's compliance in Indonesia. The attributes of personal taxpayer's compliance proposed in this research are: awareness, knowledge, perceived equality and fairness, compliance cost, fiscal service quality, tax socialization, tax regulation, tax audit and penalties. The data was gathered from 350 personal taxpayers registered in tax offices of several provinces of Indonesia. The data was processed using Second Order Confirmatory Factor Analysis (SEM-PLS) - SmartPLS 3. The result of the study confirmed that the attributes of awareness, positively, manifest the taxpayer's compliance. It is also confirmed that the attributes of knowledge, positively, manifest the taxpayer's compliance. The attributes of compliance cost, positively, manifest the taxpayer's compliance. The attributes of perceived equality and fairness, positively, manifest the taxpayer's compliance. The attributes of fiscal quality service, positively, manifest the taxpayer's compliance. The attributes of tax socialization, positively, manifest the taxpayer's compliance. The attributes of tax regulation, positively, manifest the taxpayer's compliance. The attributes of tax audit, positively, manifest the taxpayer's compliance. The attributes of penalties, positively, manifest the taxpayer's compliance. These can be concluded that all of the attributes of the constructs confirm to indicate or manifest the personal taxpayer's compliance in Indonesia.
\end{abstract}

Keywords: personal taxpayer's compliance, awareness, knowledge, perceived equality and fairness, compliance cost, fiscal service quality, tax socialization, tax regulation, tax audit, penalties.

JEL Classification : H21,H24,H26

Article info:

Received 1 December 2018

Revised 11 December 2018

Accepted 29 December 2018

Available online 31 December 2018

\section{INTRODUCTION}

Tax plays an important role in national development both for developed and underdeveloping countries. In the posture of the State Budget and Expenditure 2018 and in the Draft State Budget and Expenditure 2019 of Indonesia, the tax revenue contributed more than 80in the domestic income scheme. Table 1 presents the tax revenue in domestic revenue scheme over period of 2018 and 2019.

Table 1. Tax Revenues in the Domestic Revenue Scheme for 2018 and 2019 (in billion)

\begin{tabular}{lcrrr}
\hline \multirow{2}{*}{ Description } & \multicolumn{2}{c}{$\mathbf{2 0 1 8}$} & \multicolumn{2}{c}{$\mathbf{2 0 1 9}$} \\
\cline { 2 - 5 } & IDR & \% & \multicolumn{1}{c}{ IDR } \\
\hline Domestic Revenue & $1.897 .643,30$ & 100.00 & $2.142 .088,80$ & 100.00 \\
Tax Revenue & $1.548 .485,00$ & 81.60 & $1.780 .995,00$ & 83.14 \\
Non-Tax Revenue & $349.158,30$ & 18.40 & $361.092,90$ & 16.86 \\
\hline Source: Financial Note and Draft of State Budget \& Expenditure of Indonesia for Fiscal Year 2019
\end{tabular}


The realization of of the target of tax revenues in the past few years has not been achieved. There was one challenge for tax officer to achieving the tax targets. It was a transformation of the taxation system in Indonesia, from official assessment becomes self assessment system. In self assessment system, the taxpayers are asked to calculate, report, and pay their taxes independently. Taxpayer's compliance is very crucial to be considered by tax officers on how they encourage taxpayers to voluntarily become an obedient (compliant) taxpayers. In terms of encouraging taxpayer compliance, the analysis of the factors that are considered by taxpayers in affecting taxpayer's compliance becomes important to study. The previous research that combines internal factors and external factors of taxpayer almost not been done. Ardy et al. (2018) examined 6 (six) factors that influence taxpayer's compliance using meta-analysis approach.

Some previous studies examined the relationship between taxpayer awareness and taxpayer compliance (Alabede, 2014; Kristanty et al. 2014; Mir'atussolihah et al 2014; Pandan, 2014; Widorini \& Nugroho, 2014; Sudrajat \& Ompusunggu, 2015; Tampubolon \& Pratomo, 2015; Eddy \& Carolina, 2015). They find that the higher the awareness of the taxpayer then higher taxpayer's compliance is concerned. In relation with knowledge of taxation, some researchers tested the relationship between taxpayer's knowledge and taxpayer's compliance (Muarifah, 2012; Ihsan, 2013; Caroko, 2014; Putri, 2015: and Ulfah, 2015). They show that knowledge of taxpayers has a positive relationship with taxpayer's compliance.

The compliance cost has positive relation with taxpayer compliance. The compliance cost refer to willingness of taxpayer to bear costs that arise in fulfilling their tax obligations. Fiscal service quality is related to taxpayer's compliance (Jatmiko, 2006; Sandi, 2010; Rajif, 2012; Rohmawati \& Rasmini, 2012; Andyastuti, et al. 2013; Ariesta \& Suryaningsih, 2013; Pandan, 2014; Puri, 2014; Kundalini, 2015 ; Mahardika, 2015; Paramartha \& Rasmini, 2015; Widyastuti, 2015; Kusuma, 2016). The equality and tax justice as perceived by taxpayers are positively associated to taxpayer's compliance (Engida \& Baisa, 2014). In developing countries the issue of tax equality and fairness has become prominent.

Tax socialization is related to taxpayer compliance (Rohmawati \& Rasmini, 2012; Andyastuti, et al. 2013; Ariesta \& Suryaningsih, 2013; Ihsan, 2013; Pamuji, et al. 2014; Putra, et al. 2014; Ananda et al. 2015; Meliala \& Inasius, 2015; Sudrajat \& Ompusunggu, 2015). Likewise, taxation policies make it easy for tax management procedures to be related to taxpayer compliance (Istiqomah, 2017). Tax audits are related to taxpayer compliance (Anjarini, et al. 2012; Andyastuti, et al. 2013; Mandagi, et al. 2014; Pandan, 2014; Sukmawati, 2015; Aprilina et al., 2016). Tax sanctions also have relevance to taxpayer compliance (Tiraada, 2013; Dharma \& Ariyanto, 2014; Putra et al., 2014; Widyastuti, 2015; Aprilina, et al. 2016; Hantoyo, et al., 2016; Kusuma, 2016;).

This study is aimed to examine the attributes of personal taxpayer compliance using the Second Order Confirmatory Analysis through the Structural Equation Model - Partial Least Square (SEM-PLS) approach. The attributes of the proposed construct consist of: awareness, knowledge, perceptions of equality and fairness, compliance costs, fiscal service quality, tax socialization, tax regulation, tax audit, and tax penalties. There was nine construct to be proposed to have positive effect on taxpayers compliance in term of individual perspective and tax office perspective.

\section{LITERATURE REVIEWS}

\subsection{Taxpayer's Compliance.}

The taxpayer's compliance is a person's compliance to fulfill his/her tax obligations in accordance with regulations or tax laws (Tiraada, 2013). Based on Minister of Finance of Republik of Indonesia Regulation No. 74/PMK.03/2012, the criteria for taxpayer compliance 
include: First, timely submitting notification letters for all types of taxes. Second, there are no tax arrears, except tax arrears that have obtained permission to repay or delay payment of taxes. Third, the financial statements are audited by public accountants or government financial supervision institutions with unqualified opinions for 3 (three) consecutive years. Fourth, they have never been convicted of committing a criminal offense in the field of taxation based on a court decision that has a fixed legal power within the last 5 (five) years.

\subsection{Personal Taxpayer perspective}

1. Taxpayer's awareness. Taxpayer's awareness is awareness that is owned by taxpayers regarding the benefits and importance of taxes for the development of a country. Recognizing that taxes are an obligation of citizens to encourage taxpayers to fulfill their tax obligations. Some of the results of previous studies indicate that the higher the awareness of taxpayers the higher the taxpayer's compliance is concerned (Herryanto and Toly, 2013; Sudrajat and Ompusunggu, 2015; Tampubolon and Pratomo, 2015; Eddy and Carolina, 2015).

2. Taxpayer's knowledge. Knowledge of taxpayers refers to the understanding of taxpayers regarding regulations, procedures, tariffs, and other matters related to tax provisions. The more understanding taxpayers of the tax provisions the greater the potential taxpayers to fulfill their tax obligations. Muarifah (2012) and Supriyati (2012) found that tax knowledge has a positive effect on tax compliance. Caroko (2014) also showed the same results that knowledge of taxes had a positive effect on the taxpayer's compliance. Likewise, Ulfa (2015) concluded that taxpayer's knowledge has a positive effect on taxpayer's compliance. This result was supported by Putri (2015) stated that taxpayer's knowledge has a positive effect on taxpayer's compliance.

3. Perception of equality and fairnes. Perception of equality and fairness of tax refer to the perception of taxpayers regarding the position of taxpayers and how taxpayers are treated fairly by the government. Engida and Baisa (2014) categorize equity and tax justice as social factors that need to be considered and have relevance to taxpayer compliance. In developing countries the issue of tax equality and fairness has become prominent.

4. Compliance cost. Taxpayer's compliance costs are all expenses/costs that are willing to be borne to taxpayers related to their tax compliance or fulfillment of their tax obligations. Savitri and Musfialdy (2016) find that compliance costs are related to taxpayer compliance. The compliance cost has a positive relation with taxpayer compliance. The compliance cost refer to the willingness of the taxpayer to bear the costs that arise in fulfilling their tax obligations. Fiscal service quality is related to taxpayer's compliance (Jatmiko, 2006; Sandi, 2010; Rajif, 2012; Rohmawati and Rasmini, 2012; Andyastuti, et al. 2013; Ariesta and Suryaningsih, 2013; Pandan, 2014; Puri, 2014; Kundalini, 2015 ; Mahardika, 2015; Paramartha and Rasmini, 2015; Widyastuti, 2015; Kusuma, 2016).

\subsection{Tax Office Perspective}

1. Fiscal service quality. Fiscal service quality refers to the quality of services provided by tax officials to the taxpayers. Service quality refers to service quality which includes hospitality, reliability of service, speed of response given to taxpayers. Good public service quality makes taxpayers not reluctant to take care of their taxes independently and have an impact on tax compliance (Jatmiko, 2006; Junita, 2008; Risnawati, 2009; Gerger et.al 2014; Dyah, 2015; Dinku 2018).

2. Tax socialization. Tax socialization is a set of activities carried out by tax officials, both directly and indirectly, to provide tax information to taxpayers. Counseling, consultation, and socialization through the internet network and other media are expected to increase the knowledge of taxpayers and ultimately improve taxpayer compliance. Tax socialization is related to taxpayer compliance (Rohmawati and Rasmini, 2012; 
Andyastuti, et al. 2013; Ariesta and Suryaningsih, 2013; Ihsan, 2013; Pamuji, et al. 2014; Putra, et al. 2014; Ananda et al. 2015; Meliala and Inasius, 2015; Santoso \& Sulasmiyati, 2015; Sudrajat and Ompusunggu, 2015).

3. Tax regulation. The research conducted by Ngadiman \& Huslin (2015) shows that the tax amnesty has a positive efffect on taxpayer's compliance. This result was also supported by Suyanto (2016) that tax amnesty had a positive effect on tax compliance and Pangkey et al (2017). The implementation of tax amnesty in Indonesia has the opportunity to be successfully implemented with the type of investigation amnesty Alberto (2015). The results supported by Ragimun (2015) showed that tax amnesty had been carried out in Indonesia but was less effective. The result of the regulation is that taxpayers have high expectations of tax amnesty and will become a habit.

4. Tax audit. Inspection (tax audit) is a series of inspection processes carried out by tax officials to taxpayers related to taxation issues. This is done to ensure that tax procedures and procedures carried out by taxpayers meet applicable standards. Tax audits are related to taxpayer's compliance (Anjarini, et al. 2012; Andyastuti, et al. 2013; Mandagi, et al. 2014; Pandan, 2014; Ginting, 2015; Sukmawati, 2015; Aprilina et al., 2016). Tax sanctions also have relevance to taxpayer compliance (Tiraada, 2013; Dharma and Ariyanto, 2014; Putra et al., 2014; Widyastuti, 2015; Aprilina, et al. 2016; Hantoyo, et al., 2016; Kusuma, 2016).

5. Tax fines and sanctions (penalties). Fines and sanctions are fines and sanctions imposed on taxpayers when the taxpayer does not fulfill his tax obligations. In some studies, fines and tax sanctions are related to taxpayer compliance. Utami and Kardinal (2013) and Jotopurnomo dan Mangoting (2013) confirmed that tax sanction has a significant effect on individual taxpayer compliance in Surabaya. These results are also supported by Fuadi (2013) tax sanctions have a positive effect on tax compliance. Septarini (2015) also concluded that tax sanctions have a positive effect on taxpayer compliance. Likewise Susmita (2016) shows that tax sanctions have a positive and significant effect on tax compliance. Tax sanctions also have relevance to taxpayer's compliance (Muliari, 2011; Tiraada, 2013; Dharma \& Ariyanto, 2014; Putra et al., 2014; Fajriyan, 2015; Widyastuti, 2015; Aprilina, et al. 2016; Hantoyo, et al., 2016; Kusuma, 2016; Pujiwidodo, 2016).

\subsection{Conceptual framework and hypothesis}

As been stated in the literature review and previous studies there are several factors that associated to taxpayer compliance. In this study, factors along with attributes/indicators are used to confirm the relationship with the personal taxpayer's compliance. Several factors tested include: Awareness of taxpayers (awareness), knowledge of taxpayers (knowledge), perceptions of equality and justice (percetpion of equality and fairness) taxation socialization (tax socialization), compliance costs (compliance costs), fines and tax sanctions (penalties), taxpayer review (tax audit), fiscal service quality (fiscal service quality) and taxation policy (tax regulation). Figure 1 describes the conceptual framework of this study. 


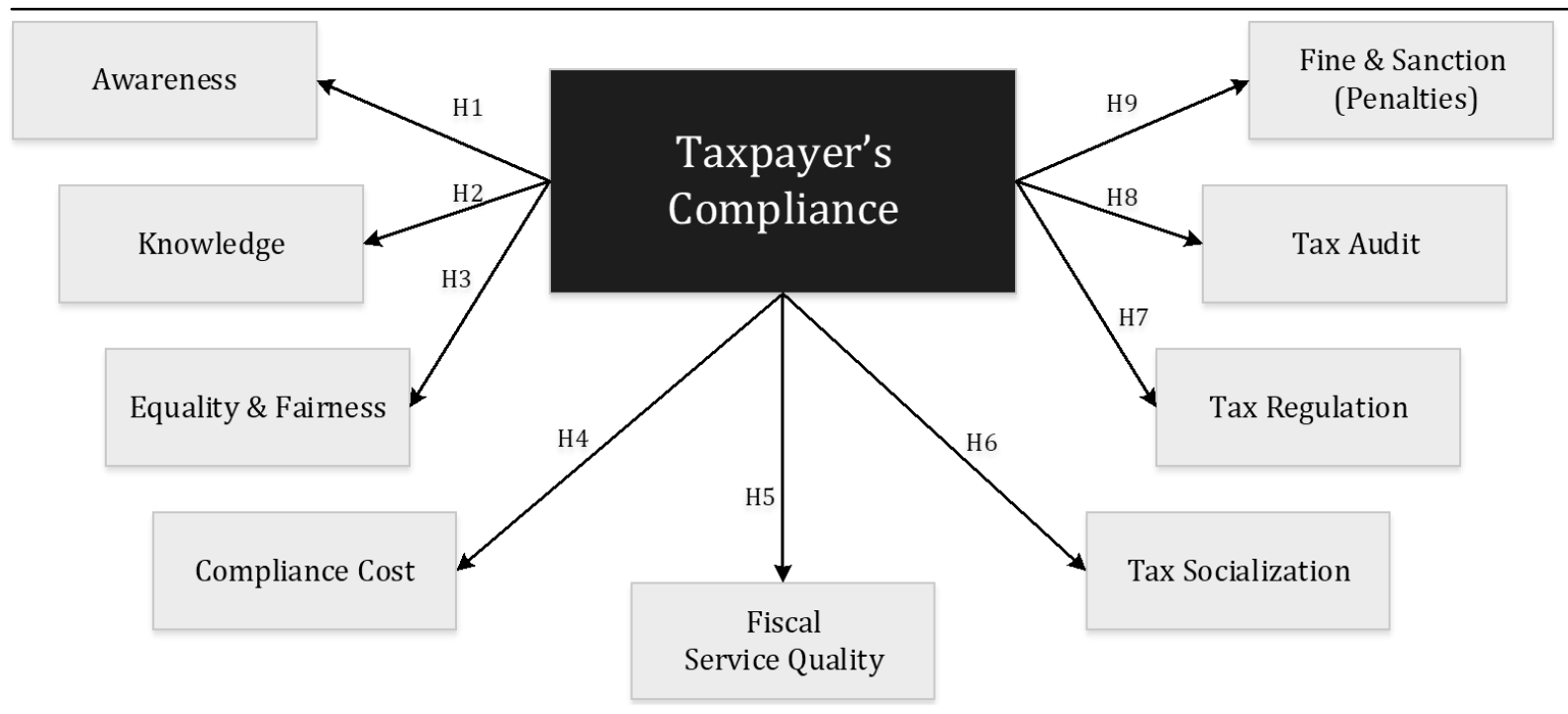

Figure 1: Conceptual Framework

Based on Figure 1 then the hypothesis in this study can be formulated as follows:

Hypothesis 1 : The attributes of taxpayer's awareness positively and significantly reflect the construct of personal taxpayer's compliance.

Hypothesis 2 : The attibutes of taxpayer's knowledge attributes positively and significantly reflects the construct of personal taxpayer's compliance.

Hypothesis 3 : The attributes of perception of equality and fairness positively and significantly reflects the construct of personal taxpayer's compliance.

Hypothesis 4 : The attributes of compliance cost positively and significantly reflects the construct of personal taxpayer's compliance.

Hypothesis 5 : The attributes of fiscal service quality positively and significantly reflects the construct of personal taxpayer's compliance.

Hypothesis 6 : The attributes of tax socialization positively and significantly reflects the construct of personal taxpayer's compliance.

Hypothesis 7 : The attributes of tax regulation positively and significantly reflects the construct of personal taxpayer's compliance.

Hypothesis 8 : The attributes of tax audit positively and significantly reflects the construct of personal taxpayer's compliance.

Hypothesis 9 : The attributes of tax fines and sanctions (penalties) positively and significantly reflects the construct of personal taxpayer's compliance.

\section{RESEARCH METHOD}

This study uses 270 personal taxpayers registered in tax officials of several provinces in Indonesia as the sample. Technically, this study distributes questionnaires for 300 respondents but only 280 respondents sent back the questionnaires. On 280 questionnaires, there are 270 questionnaires filled in complete. Table 2 describes all attributes of all proposed constructs that manifest personal taxpayer's compliance. 


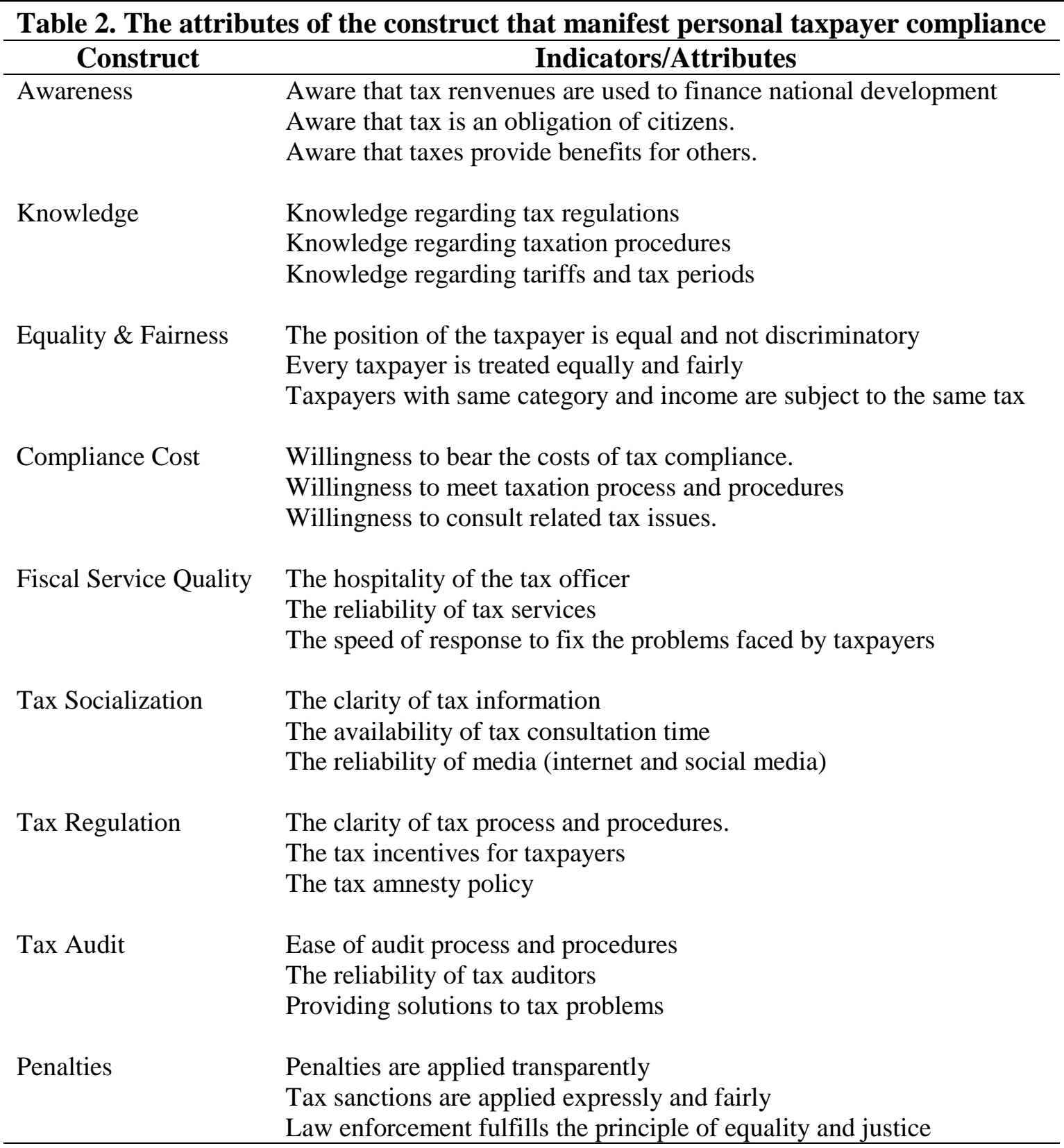

All of the attributes in each construct are measured using a 5 points of Likert scale. To confirm that the attributes of the construct are significant in indicating or reflecting constructs are tested using the Second Order Confirmatory Factor Analysis (Second Order CFA) through the Structural Equation Model - Partial Least Square (SEM-PLS) approach using SmartPLS 3.0.

\section{RESULTS AND DISCUSSIONS}

The Second Order Confirmatory Factor Analysis (Second Order - CFA) is used to test the proposed hypotheses. First, the significance test of the outer loading of all attributes in reflecting/manifesting the constructs of taxpayer compliance. Second, the significance test of constructs in reflecting/manifesting taxpayer's compliance. PLS analysis is conducted in two stages. The first stage is to evaluate the measurement model for each latent construct. At this stage, to test and assess the validity and reliability of measurements. The second stage is to conduct a second order confirmatory factor analysis. In the PLS analysis, Chin, Marcolin \& Newsted (2003) suggested that the adequacy of measurements is assessed by evaluating three 
components; (1) individual item reliability, (2) internal consistency of items that measure the respective latent construct, and (3) discriminant validity of the construct.

The reliability of indicator is assessed through the loading factors of the respective construct. The bigger the loading factor of an indicator to respective construct, the more reliable the indicator in manifesting its construct. The measurement of internal consistency is assessed using Composite Reliability (CR) with the required value above 0.7. The last indicator is average variance extracted (AVE), the expected value for AVE is above 0.5.

Table 3. Reliability, internal consistency, and average variance extracted

\begin{tabular}{lcrr}
\hline \multicolumn{1}{c}{ Construct } & R & Composite Reliability & AVE \\
\hline Awareness & 0.584 & 0.921 & 0.795 \\
Knowledge & 0.722 & 0.728 & 0.491 \\
Equality \& Fairness & 0.501 & 0.905 & 0.761 \\
Compliance Cost & 0.652 & 0.783 & 0.548 \\
Fiscal Service Quality & 0.715 & 0.820 & 0.604 \\
Tax Socialization & 0.554 & 0.803 & 0.577 \\
Tax Regulation & 0.601 & 0.849 & 0.657 \\
Tax Audit & 0.677 & 0.731 & 0.481 \\
Penalties & 0.527 & 0.763 & 0.521 \\
\hline
\end{tabular}

Table 3 shows that all of the construct of taxpayer's compliance consist of: awareness, knowledge, equality \& fairness, compliance cost, fiscal service quality, tax socialization, tax regulation, tax audit and penalties are reliable. Its indicated by the composite reliability score were above 0.7. Besides, knowledge and tax audit constructs have the AVE score below 0.5.

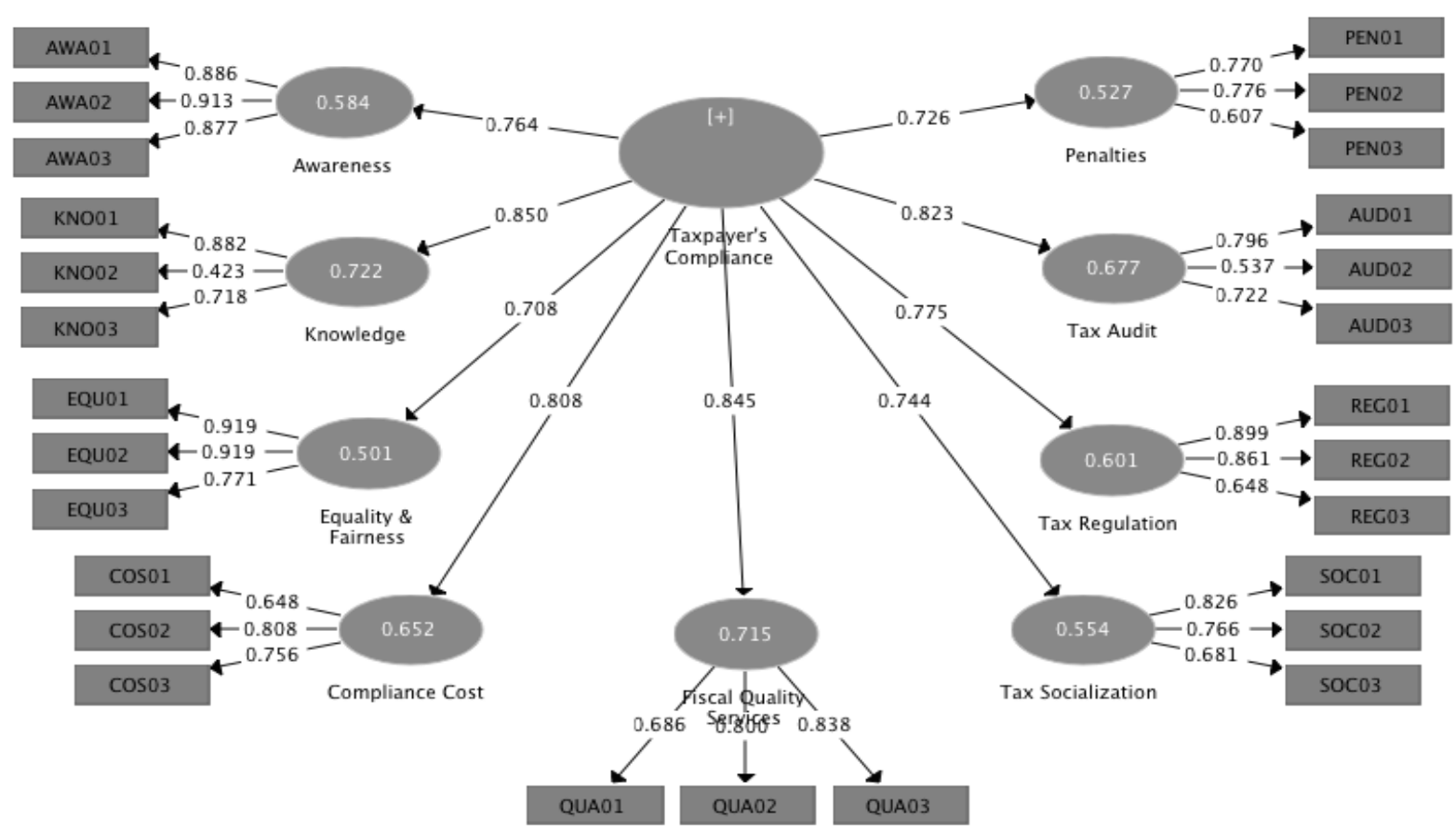

Figure 2: Second order confirmatory factor analysis personal taxpayer compliance attributes 


\section{Taxpayer Compliance Attributes - First Order Confirmatory Factor Analysis}

The attributes of awareness. Statistically, indicators are stated to have reflective ability to proxy latent variables as stated in the amount of loading factor. To test the significance of attributes in reflecting/manifesting latent variables, the $s_{\text {tatistics }}$ must be greater than 1.96 and the probability ( $\mathrm{p}$-values) must be lower than 0.05 . Table 4 presents the $\mathrm{t}_{\text {statistic }}$ of the attributes in the taxpayer's awareness construct. Table 4 shows that result of First Order Confirmatory Factor Analysis, the outer loading factor of all attributes manifest the construct of awareness of the taxpayers. The higher the loading factor (original sample and sample mean) then better the attribute to reflect/manifest the construct of awareness of the taxpayer. The test results show that $t_{\text {statistics }}$ is higher than 1.96 and $p_{\text {value }}$ is lower than 0.05 , so all of the attributs, significantly, reflect/manifest the construct of taxpayer's awareness.

Table 4. Manifestations of the attributes of taxpayer awareness

\begin{tabular}{crrrrr}
\hline Construct & $\begin{array}{c}\text { Original } \\
\text { Sample (O) }\end{array}$ & $\begin{array}{c}\text { Sample } \\
\text { Mean (M) }\end{array}$ & $\begin{array}{c}\text { Standard } \\
\text { Deviation }\end{array}$ & $\begin{array}{c}\text { T Statistic } \\
\text { (IO/STDEV) }\end{array}$ & P Values \\
\hline AUD01 <-- Tax Audit & 0.796 & 0.800 & 0.034 & 23.251 & 0.000 \\
AUD02 <-- Tax Audit & 0.537 & 0.532 & 0.122 & 4.409 & 0.000 \\
AUD03 <-- Tax Audit & 0.722 & 0.712 & 0.071 & 10.198 & 0.000 \\
\hline
\end{tabular}

The attributes of knowledge. The loading factors (original sample and sample mean) shows the ability of attributes to reflect/manifest measured construct. Table 5 presents the $t_{\text {statistic }}$ of the attributes of taxpayer's knowledge construct. Table 5 shows that result of First Order Confirmatory Factor Analysis, the outer loading factor of all attributes manifest the construct of knowledge of the taxpayer. The higher the loading factor (original sample and sample mean) then better attributes to reflect/manifest construct of knowledge of taxpayer. The test results show that $\mathrm{t}_{\text {statistics }}$ is higher than 1.96 and $\mathrm{p}_{\text {value }}$ is lower than 0.05 , so all of attributes, significantly, reflect/manifest the construct of knowledge of the taxpayers.

Table 5. Manifestations of the attribbutes of taxpayer's knowledge

\begin{tabular}{lrrrrr} 
Construct & \multicolumn{1}{c}{$\begin{array}{c}\text { Original } \\
\text { Sample (O) }\end{array}$} & $\begin{array}{c}\text { Sample } \\
\text { Mean (M) }\end{array}$ & $\begin{array}{c}\text { Standard } \\
\text { Deviation }\end{array}$ & $\begin{array}{c}\text { T Statistic } \\
(\text { IO/STDEV) }\end{array}$ & P Values \\
\hline <-- Awareness & 0.886 & 0.884 & 0.031 & 28.184 & 0.000 \\
<-- Awareness & 0.913 & 0.912 & 0.023 & 40.115 & 0.000 \\
<-- Awareness & 0.877 & 0.877 & 0.034 & 25.513 & 0.000 \\
\hline
\end{tabular}

Equality and fairness attributes. The loading factors (original sample and sample mean) shows the ability of attributes to reflect/manifest the measured construct. Table 6 presents the $t_{\text {statistic }}$ of the attributes in the construct of perceived equality and fairnes. Table 6 shows that result of First Order Confirmatory Factor Analysis, the outer loading factor of all attributes manifest the construct of perceived equality and fairness. The higher the loading factor (original sample and sample mean), the better the attribute to reflect/manifest the construct of equality and fairness. The test results show that the $t_{\text {statistics }}$ is higher than 1.96 and $\mathrm{p}_{\text {value }}$ is lower than 0.05 , so all attributes, significantly, reflect/manifest the construct of perceived equality and fairness. 
Table 6. Manifestations of the attributes of perceived equality and fairness

Original

Construct

Sample

Sample Standard T Statistic

(O)

EQU01 <-- Equality and fairness

0.919

Mean (M) Deviation (IO/STDEV)

P Values

EQU01 <-- Equality and fairness

0.919

0.919

0.018

51.304

0.000

EQU01 <-- Equality and fairness

0.771

0.921

0.019

49.527

0.000

The attributes of compliance cost. The loading factors (original sample and sample mean) shows the ability of attributes to reflect/manifest the measured construct. Table 7 presents the $t_{- \text {statistic }}$ of the attributes in the construct of compliance costs. Table 7 shows that the result of First Order Confirmatory Factor Analysis, the outer loading factor of all attributes manifest the construct of compliance costs. The higher the loading factor (original sample and sample mean), the better the attributes to reflect/manifest the construct of compliance costs. The test results show that the $t_{\text {statistics }}$ is higher than 1.96 and $p_{\text {value }}$ is lower than 0.05 , so all attributes, significantly, reflect/manifest the construct of compliance costs.

Table 7. Manifestation of the attributes of compliance cost

\begin{tabular}{lccccc}
\hline \multicolumn{1}{c}{ Construct } & $\begin{array}{c}\text { Original } \\
\text { Sample (O) }\end{array}$ & $\begin{array}{c}\text { Sample } \\
\text { Mean (M) }\end{array}$ & $\begin{array}{c}\text { Standard } \\
\text { Deviation }\end{array}$ & $\begin{array}{c}\text { T Statistic } \\
(\text { IO/STDEV) }\end{array}$ & P Values \\
\hline COS01 <-- Compliance cost & 0.648 & 0.651 & 0.067 & 9.662 & 0.000 \\
COS01 <-- Compliance cost & 0.808 & 0.800 & 0.053 & 15.295 & 0.000 \\
COS01 <-- Compliance cost & 0.756 & 0.750 & 0.051 & 14.725 & 0.000 \\
\hline
\end{tabular}

The attributes of fiscal service quality. The loading factors (original sample and sample mean) shows the ability of attributes to reflect/manifest the measured construct. Table 8 presents the $t_{\text {statistic }}$ of the attributes in the construct of fiscal service quality. Table 8 shows that the result of the First Order Confirmatory Factor Analysis, the outer loading factor of all attributes manifest the construct of fiscal service quality. The higher loading factor (original sample and sample mean) then better attribute to reflect/manifest the construct of fiscal service quality. The test results shows that $\mathrm{t}_{\text {statistics }}$ is higher than 1.96 and $\mathrm{p}_{\mathrm{value}}$ is lower than 0.05 , so all attributes are significantly reflect/manifest construct of quality of fiscal services.

Table 8. Manifestations of the attributes of fiscal service quality

\begin{tabular}{lccccc}
\hline \multicolumn{1}{c}{ Construct } & $\begin{array}{c}\text { Original } \\
\text { Sample } \\
(\mathbf{O})\end{array}$ & $\begin{array}{c}\text { Sample } \\
\text { Mean } \\
(\mathbf{M})\end{array}$ & $\begin{array}{c}\text { Standard } \\
\text { Deviation }\end{array}$ & $\begin{array}{c}\text { T Statistic } \\
(\text { IO/STDEV) }\end{array}$ & P Values \\
\hline QUA01 <-- Fiscal Service Quality & 0.686 & 0.676 & 0.083 & 8.224 & 0.000 \\
QUA02 <-- Fiscal Service Quality & 0.800 & 0.799 & 0.044 & 18.319 & 0.000 \\
QUA03 <-- Fiscal Service Quality & 0.838 & 0.840 & 0.033 & 25.634 & 0.000 \\
\hline
\end{tabular}

The attributes of tax socialization. The loading factors (original sample and sample mean) show the ability of attributes to reflect/manifest the measured construct. Table 9 presents the $t_{\text {statistics }}$ of the attributes in the construct of tax socialization. Table 9 shows that the result of the First Order Confirmatory Factor Analysis, the outer loading factor of all attributes manifest the construct of tax socialization. The higher the loading factor (original sample and sample mean), the better the attribute to reflect/manifest the construct of tax socialization. The test results show that $\mathrm{t}_{\text {statistics }}$ is higher than 1.96 and $\mathrm{p}_{\text {value }}$ is lower than 0.05 , so all attributes, significantly, reflect/manifest the construct of tax socialization. 
Table 9. Manifestations of the attributes of tax socialization

\begin{tabular}{lccccc}
\hline \multicolumn{1}{c}{ Construct } & $\begin{array}{c}\text { Original } \\
\text { Sample (O) }\end{array}$ & $\begin{array}{c}\text { Sample } \\
\text { Mean (M) }\end{array}$ & $\begin{array}{c}\text { Standard } \\
\text { Deviation }\end{array}$ & $\begin{array}{c}\text { T Statistic } \\
(\text { IO/STDEV) }\end{array}$ & P Values \\
\hline SOC <-- Tax Socialization & 0.826 & 0.822 & 0.043 & 19.080 & 0.000 \\
SOC <-- Tax Socialization & 0.766 & 0.763 & 0.055 & 13.907 & 0.000 \\
SOC <-- Tax Socialization & 0.681 & 0.680 & 0.078 & 8.698 & 0.000 \\
\hline
\end{tabular}

The attributes of tax regulation. The loading factors (original sample and sample mean) show the ability of attributes to reflect/manifest the measured construct. Table 10 presents the $t_{\text {statistic }}$ of the attributes in the tax policy construct. Table 10 shows that the result of the First Order Confirmatory Factor Analysis, the outer loading factor of all attributes manifest the construct of tax regulation. The higher the loading factor (original sample and sample mean), the better the attributes to reflect/manifest the construct of tax regulation. The test results show that the $t_{\text {statistics }}$ is higher than 1.96 and $p_{\text {value }}$ is lower than 0.05 , so all attributes, significantly, reflect/manifest the construct of tax regulation.

Table 10. Manifestations the attributs of tax regulation

\begin{tabular}{lccccc}
\hline \multicolumn{1}{c}{ Construct } & $\begin{array}{c}\text { Original } \\
\text { Sample (O) }\end{array}$ & $\begin{array}{c}\text { Sample } \\
\text { Mean (M) }\end{array}$ & $\begin{array}{c}\text { Standard } \\
\text { Deviation }\end{array}$ & $\begin{array}{c}\text { T Statistic } \\
(\text { IO/STDEV) }\end{array}$ & P Values \\
\hline REG01 <-- Tax Regulation & 0.899 & 0.896 & 0.024 & 37.280 & 0.000 \\
REG02 <-- Tax Regulation & 0.861 & 0.858 & 0.044 & 15.590 & 0.000 \\
REG03 <-- Tax Regulation & 0.648 & 0.649 & 0.061 & 10.545 & 0.000 \\
\hline
\end{tabular}

The attributes of tax audit. The loading factors (original sample and sample mean) show the ability of attributes to reflect / manifest the measured construct. Table 11 presents the $t_{\text {statistic }}$ of the attributes in the construct of tax audit. Table 11 shows that the result of the First Order Confirmatory Factor Analysis, the outer loading factor of all attributes manifest the construct of tax audit. The higher the loading factor (original sample and sample mean), the better the attribute to reflect/manifest the construct of tax audit. The test results show that $\mathrm{t}_{\text {statistics }}$ is higher than 1.96 and $\mathrm{p}_{\text {value }}$ is lower than 0.05 , so that all attributes, significantly, reflect/manifest of tax audit.

Table 11. Manifestations of the attributes tax audit

\begin{tabular}{lccccc}
\hline \multicolumn{1}{c}{ Construct } & $\begin{array}{c}\text { Original } \\
\text { Sample (O) }\end{array}$ & $\begin{array}{c}\text { Sample } \\
\text { Mean (M) }\end{array}$ & $\begin{array}{c}\text { Standard } \\
\text { Deviation }\end{array}$ & $\begin{array}{c}\text { T Statistic } \\
(\text { IO/STDEV) }\end{array}$ & P Values \\
\hline AUD01 <-- Tax Audit & 0.796 & 0.800 & 0.034 & 23.251 & 0.000 \\
AUD02 <-- Tax Audit & 0.537 & 0.532 & 0.122 & 4.409 & 0.000 \\
AUD03 <-- Tax Audit & 0.722 & 0.712 & 0.071 & 10.198 & 0.000 \\
\hline
\end{tabular}

The attributes of fines and sanctions (penalties). The loading factors (original sample and sample mean) show the ability of attributes to reflect/manifest the measured construct. Table 12 The $t_{\text {statistic }}$ of the attributes in the fine and sanction (penalties) construct. Table 12 shows that the result of the First Order Confirmatory Factor Analysis, the outer loading factor of all attributes manifest fine and sanction (penalties) constructs. The higher the loading factor (original sample and sample mean), the better the attributes to reflect/manifest the construct of fines and sanctions (penalties). The test results show that $\mathrm{t}_{\text {statistics }}$ is higher than 1.96 and $\mathrm{p}_{\text {value }}$ is lower than 0.05 , so that all attributes, significantly, reflect/manifest of construct of fines and sanctions (penalties). 
Table 12. Manifestations of fines and sanctions attributes

\begin{tabular}{lccccc}
\hline Construct & $\begin{array}{c}\text { Original } \\
\text { Sample (O) }\end{array}$ & $\begin{array}{c}\text { Sample } \\
\text { Mean (M) }\end{array}$ & $\begin{array}{c}\text { Standard } \\
\text { Deviation }\end{array}$ & $\begin{array}{c}\text { T Statistic } \\
(\text { IO/STDEV) }\end{array}$ & P Values \\
\hline PEN01 <-- Penalties & 0.770 & 0.767 & 0.057 & 13.453 & 0.000 \\
PEN02 <-- Penalties & 0.776 & 0.772 & 0.057 & 13.519 & 0.000 \\
PEN03 <-- Penalties & 0.607 & 0.596 & 0.095 & 6.363 & 0.000 \\
\hline
\end{tabular}

The Hypothesis Testing - Second Order Confirmatory Factor Analysis. To test the hypotheses, this study have to the inner loading factor and the level of significance $\left(t_{\text {statistic }}\right.$ and $\left.\mathrm{p}_{\text {value }}\right)$. The higher the loading factor then greater the manifestation/reflection of one construct to another. The influence of the construct is statistically significant if the $t_{\text {statistic }}$ is higher than 1.96 and the $p_{\text {value }}$ is lower than 0.05 at the interval of the $95 \%$ confidence level. Table 13 presents the results of hypotheses testing using the Second Order Confirmatory Factor Analysis.

Table 13. Hypothesis testing results

\begin{tabular}{|c|c|c|c|c|c|c|}
\hline & $\begin{array}{c}\text { Original } \\
\text { Sample } \\
(O)\end{array}$ & $\begin{array}{l}\text { Sample } \\
\text { Mean } \\
\text { (M) }\end{array}$ & $\begin{array}{l}\text { Standard } \\
\text { Deviation }\end{array}$ & $\begin{array}{c}\text { T Statistic } \\
\text { (IO/STDEV) }\end{array}$ & P Values & $\begin{array}{c}\text { Hypothesis } \\
\text { Testing }\end{array}$ \\
\hline $\begin{array}{l}\text { Taxpayer's } \\
\text { Compliance <-- } \\
\text { Awareness }\end{array}$ & 0.764 & 0.760 & 0.046 & 16.491 & 0.000 & $\begin{array}{l}\text { Positive } \\
\text { Significant }\end{array}$ \\
\hline $\begin{array}{l}\text { Taxpayer's } \\
\text { Compliance <-- } \\
\text { Knowledge }\end{array}$ & 0.850 & 0.847 & 0.029 & 28.882 & 0.000 & $\begin{array}{l}\text { Positive } \\
\text { Significant }\end{array}$ \\
\hline $\begin{array}{l}\text { Taxpayer's } \\
\text { Compliance <-- } \\
\text { Equality \& } \\
\text { Fairness }\end{array}$ & 0.708 & 0.702 & 0.058 & 12.207 & 0.000 & $\begin{array}{l}\text { Positive } \\
\text { Significant }\end{array}$ \\
\hline $\begin{array}{l}\text { Taxpayer's } \\
\text { Compliance <-- } \\
\text { Compliance Cost }\end{array}$ & 0.808 & 0.807 & 0.038 & 21.037 & 0.000 & $\begin{array}{l}\text { Positive } \\
\text { Significant }\end{array}$ \\
\hline $\begin{array}{l}\text { Taxpayer's } \\
\text { Compliance <-- } \\
\text { Fiscal Quality } \\
\text { Service }\end{array}$ & 0.845 & 0.846 & 0.027 & 31.593 & 0.000 & $\begin{array}{l}\text { Positive } \\
\text { Significant }\end{array}$ \\
\hline $\begin{array}{l}\text { Taxpayer's } \\
\text { Compliance <-- } \\
\text { Tax Socialization }\end{array}$ & 0.744 & 0.745 & 0.037 & 20.064 & 0.000 & $\begin{array}{l}\text { Positive } \\
\text { Significant }\end{array}$ \\
\hline $\begin{array}{l}\text { Taxpayer's } \\
\text { Compliance <-- } \\
\text { Tax Regulation }\end{array}$ & 0.775 & 0.774 & 0.041 & 19.001 & 0.000 & $\begin{array}{l}\text { Positive } \\
\text { Significant }\end{array}$ \\
\hline $\begin{array}{l}\text { Taxpayer's } \\
\text { Compliance <-- } \\
\text { Tax Audit }\end{array}$ & 0.823 & 0.826 & 0.032 & 25.421 & 0.000 & $\begin{array}{l}\text { Positive } \\
\text { Significant }\end{array}$ \\
\hline $\begin{array}{l}\text { Taxpayer's } \\
\text { Compliance <-- } \\
\text { Penalties }\end{array}$ & 0.726 & 0.722 & 0.060 & 12.188 & 0.000 & $\begin{array}{l}\text { Positive } \\
\text { Significant }\end{array}$ \\
\hline
\end{tabular}


The results of hypothesis testing using the Second Order Confirmatory Factor Analysis (SEM PLS) show that the loading factor of taxpayer's compliance as reflected by the taxpayer's awareness construct is 0.764 , the $t_{\text {statistic }}$ is 16.491 and the $p_{\text {value }}$ is 0.000 . Statistically, the hypothesis 1: The attributes of taxpayer's awareness, positively and significantly, reflect/manifest the personal taxpayer's compliance is supported. The higher the awareness of the taxpayers, the higher the taxpayer's compliance of the individual concerned. The loading factor of taxpayer compliance as reflected by the knowledge of the taxpayer is 0.850 , the $t_{\text {statistic }}$ is 28.882 and the $p_{\text {value }}$ is 0.000 . Statistically, the hypothesis $2:$ The attributes of taxpayer knowledge, positively and significantly, reflect/manifest personal taxpayer's compliance is supported. The more knowledge of personal taxpayers, the higher the taxpayer's compliance of the individual concerned.

The loading factor of taxpayer compliance as reflected by the construct of perceptions of equality and fairness is 0.708 , the $t_{\text {statistic }}$ is 12.207 and the $p_{\text {value }}$ is 0.000 . Statistically, Hypothesis 3: The Attributes of perceptions of equality and fairness positively and significantly can reflect statutory taxpayer compliance statistically supported. The better the perception of equality and justice of personal taxpayers, the higher the taxpayer's compliance of the individual concerned.

The loading factor of taxpayer compliance, reflected by the construct of compliance costs, is 0.807 and the $t_{\text {statistics }}$ is 21.037 and the $p_{\text {value }}$ is 0.000. Statistically, Hypothesis 4: The attributes of compliance cost, positively and significantly, reflect personal taxpayer compliance is supported. The greater the willingness of personal taxpayers to bear the costs of compliance, the higher the taxpayer's compliance of the individual concerned.

The loading factor of taxpayer compliance as reflected by the construct of fiscal service quality is $0.846, \mathrm{t}_{\text {statistic }}$ is 31,593 and $\mathrm{p}_{\text {value }}$ is 0,000 . Statistically, the hypothesis 5: The attributes of fiscal service quality, positively and significantly, reflect/manifest personal taxpayers compliance is supported. The better the quality of fiscal services as perceived by personal taxpayers, the higher the taxpayer's compliance of the individual concerned.

The loading factor of taxpayer's compliance as reflected by the tax socialization construct is 0.744 , the $t_{\text {statistic }}$ is 20.064 and the $p_{\text {value }}$ is 0.000 . Statistically, the hypothesis 6 : The attributes of tax socialization, positively and significantly, reflect personal taxpayer's compliance is supported. The better and more informative socialization of taxation, the higher the taxpayer's compliance with the individual concerned.

The loading factor of taxpayer compliance reflected by the tax policy construct is 0.775 and the $t$ statistic is 19.001 and the $p_{\text {value }}$ is 0.000. Statistically, Hypothesis 7: The attributes of tax regulation, positively and significantly, reflect personal taxpayer compliance supported. The better the tax regulation, the higher the taxpayer's compliance with the individual concerned.

The loading factor of taxpayer compliance is reflected by the tax audit construct is 0.823 , the $t_{\text {statistic }}$ is 25.421 , and the $\mathrm{p}_{\text {value }}$ of 0.000 . Statistically, the hypothesis 8: The attributes of tax audit, positively and significantly, reflect personal taxpayer compliance is supported. The better the procedure of tax audit, the higher the taxpayer's compliance with the individual concerned.

The loading factor of taxpayer's compliance as reflected by the construct of fines and sanctions (penalties) is 0.726 , the $t_{\text {statistic }}$ is 12.188 and $p_{\text {value }}$ is 0.000 . Statistically, the hypothesis 9: The Attributes of fines and sanctions (penalties), positively and significantly, reflect personal taxpayer compliance is supported. The more stringent of fines and sanctions (penalties), the higher the taxpayer's compliance of the individual concerned. 


\section{CONCLUSION} follows:

Based on the results of the result analysis above, the conclusion of the research are as

1. The personal taxpayer's compliance is driven by internal factors of taxpayers: taxpayer's awareness, taxpayer's knowledge, perceptions of equality and fairness, and willingness to bear compliance costs.

2. The personal taxpayer's compliance is also driven by external factors of taxpayers (social factors and tax institutions): fiscal service quality, tax socialization, tax regulation, tax audit, and penalties.

3. All of the attributes of nine constructs reflect/manifest the taxpayer's compliance.

In Indonesia, the taxation system transforms from official assessment to self assessment system, in which the system gives the taxpayer confidence to register, calculate, pay and report his/her own tax obligations. The taxpayer's compliance manifested by awareness, knowledge, perceptions of equality and fairness, and the willingness of taxpayers to bear the costs of compliance are very important factors. From the tax official side, the advance of fiscal service quality, tax socialization, tax regulation, tax audit and penalties have to be practiced intensively.

\section{REFERENCES}

Alabede, J. O. (2014). An Exploratory Analysis of Individual Taxpayers' Compliance Behaviour in Nigeria: a Study of Demographic Differences and Impact. International Journal of Accounting, 2(2), 39-64.

Ananda, P. R. D., Kumadji, S., \& Husaini, A. (2015). The effect of taxation socialization, tax rates, and understanding of taxation on tax compliance (studies on SMEs registered as taxpayers at the Pratama Batu Tax Service Office). Journal of Taxation (JEJAK), 6.

Andyastuti, L., Topowijono, \& Husaini, A. (2013). The effect of counseling, service, examination and sanctions on the delivery of personal notification letters (studies at the North Malang Pratama Tax Service Office). Journal of Business Administration, 2(2).

Anjarini, K., Prasetyo, B. H., \& Irani, L. D. (2012). Analysis of the implementation of tax audits in improving individual taxpayer compliance at KPP Pratama Jakarta Sawah Besar Satu. Journal of Tax Accounting, 1-8.

Aprilina, K. R., Made, A., \& Dianawati, E. (2016). The effect of tax collection, tax audit and tax sanctions on the level of tax compliance at the Kepanjen Primary Tax Office. Journal of Accounting Student Research, 4(2), 1-17.

Ardy, A., Kristanto, A. B., \& Damayanti, T. W. (2018). Indonesian Taxpayers' Compliance: A Meta-Analysis. Accounting and Finance Research, 7(3), 29.

Ariesta, C., \& Suryaningsih, R. (2013). The influence of the quality of tax services and the application of tax sanctions on individual taxpayer compliance at KPP Pratama Kosambi. Ultima Accounting, 5(1), 36-54.

Caroko, Bayu. (2014). Effect of Tax Knowledge, Quality of Tax Services and Tax Sanctions Against Motivation of Individual Taxpayers in Paying Taxes. Journal of Taxation. Brawijaya University.

Dharma, M. T., \& Ariyanto, S. (2014). Analysis of factors that influence the level of compliance of individual taxpayers in the environment of the Pratama Tigaraksa KPP Tangerang. Binus Business Review, 5(2), 497-509.

Dinku, T., \& A, A. (2018). External Factors Affecting Voluntary Taxpayers Compliance: The Case of Amhara National Regional State Revenue Authorities. Journal of Business \& 
Financial Affairs, 7(1), 1-6.

Dyah, D. K. N., Handayani, S. R., \& Sulasmiyati, S. (2015). The influence of knowledge of tax and quality of service tax authorities on taxpayer compliance (study on corporate taxpayers at Jember Primary Tax Office). Student Tax Journal, 5(1).

Eddy, E. P. S., \& Carolina, V. (2015). The effect of the level of knowledge of taxation of individual taxpayers on taxpayer compliance at the Faculty of Economics at Maranatha Christian University. 2015, 7(1), 1-13.

Fajriyan, Nur Afianti. (2015). Effect of Perception of National Tax Census Implementation, Taxpayer Attitude on Implementation of Penalties Sanctions and Tax Awareness on Taxpayer Compliance (Study on Individual Taxpayers in Miji Village, Mojokerto City). Journal. Brawijaya University.

Gerger, G. Ç., Gerçek, A., Taşkın, Ç., Bakar, F., \& Güzel, S. (2014). Determining the Factors That Affect Taxpayers' Perspective on Tax Administration: Research in Turkey. International Journal of Economics and Finance Studies, 6(1), 1309-8055.

Ginting, R. P. (2015). Effect of tax audit on taxpayer compliance (study at the Malang Tax Office). Student Tax Journal, 6(1).

Hantoyo, S. S., Kertahadi, \& Handayani, S. R. (2016). The effect of tax avoidance and tax sanctions on taxpayer compliance. Tax Journal (JEJAK), 9(1), 1-7.

Herryanto, M., \& Toly, A. A. (2013). Effect of taxpayer awareness, tax socialization activities, and tax audit on income tax receipts at Sawahan KPP Pratama Surabaya. Tax \& Accounting Review, 1(1), 124-135.

Ihsan, M. (2013). Effect of taxpayer knowledge, tax counseling, tax service quality and tax audit on corporate taxpayer compliance in Padang City. Journal of Tax Accounting, $1(3), 1-31$.

Istiqomah. (2017). Analysis of the compliance of individual taxpayers related to the existence of a tax sanction removal policy. Nominal Journal, VI, 81-92.

Jatmiko, A. N. (2006). The effect of taxpayer attitudes on the implementation of fines, tax services and tax awareness of taxpayer compliance (empirical studies of individual taxpayers in Semarang). Thesis. Diponegoro University.

Jotopurnomo, Cindy dan Yenni Mangoting. (2013). The Influence of Taxpayer Awareness, Fiscal Service Quality, Tax Sanctions, Taxpayers' Environment Resides to the Compliance of Individual Taxpayers in Surabaya. Petra Christian University. Tax \& Accounting Review, Vol.1, No.1, 2013.

Junita, I., \& Widiastuti, R. (2008). SERVQUAL approach in evaluating the quality of service of the tax office. Journal of Management Studies, COMPETENCE 2(1), 42-45.

Kundalini, P. (2015). The effect of taxpayer awareness and tax employee service on taxpayer compliance at Temanggung Regency KPP 2015. Thesis. Yogyakarta State University.

Kusuma, K. C. (2016). Effect of tax service quality, understanding of tax regulations, and tax sanctions on individual taxpayer compliance in paying taxes in 2014 (case studies on taxpayers registered with Wonosobo KPP). Thesis. Yogyakarta State University.

Mahardika, I. G. P. (2015). Effect of service quality and attitude of taxpayers on compliance with individual taxpayer reporting at KPP Pratama Singaraja. Journal of the Department of Economic Education, 5(1), 1-12.

Meliala, A. N. K. S., \& Inasius, F. (2015). The influence of the quality of tax authorities services and tax socialization on individual taxpayer compliance imposed by PP No. 46 of 2013. Thesis. Bina Nusantara University.

Mir'atusholihah, Kumadji, S., \& Ismono, B. (2014). Effect of tax knowledge, tax service quality and tax rates on taxpayer compliance (studies on MSME taxpayers in North Malang KPP Pratama). Student Tax Journal, 3(1), 1-10.

Muliari, N. K., \& Setiawan, P. E. (2011). Effect of perceptions of tax sanctions and taxpayer 
awareness on compliance with individual taxpayer reporting at the East Denpasar Pratama Tax Office. Accounting and Business Scientific Journal, 6(1), 1-23.

Ngadiman, \& Huslin, D. (2015). Effect of sunset policy, tax amnesty, tax sanctions on taxpayer compliance. Journal of Tax Accounting, XIX(2), 225-241.

Pandan, S. H. (2014). he influence of knowledge of taxation, service quality, inspection and awareness of taxpayer compliance (empirical studies of employees of the Jember Central Bureau of Statistics Office). Thesis. University of Jember.

Pangkey, Milka Magrita,. Sondakh, J. J., \& Tirayoh, V. Z. (2017). Analysis of Compliance with Individual Taxpayers Before and After the Implementation of Tax Amnesty in Manado Primary Tax Office 1, 12(2), 513-522.

Paramartha, I. P. I. P., \& Rasmini, N. K. (2015). Effect of service quality, knowledge and tax sanctions on corporate taxpayer compliance. E-Journal of Accounting of Udayana University, 15(1), 641-666.

Pujiwidodo, D. (2016). Perception of tax sanctions on individual taxpayer compliance. Online Journal of Accountant Persons, 1(1), 92-116.

Puri, K. A. (2014). The influence of taxpayer awareness, tax authorities and tax sanctions on taxpayer compliance of individuals who carry out business activities and free work. Thesis. Muhamadiyah University Surakarta.

Putra, R. R. R., Handayani, S. R., \& Topowijoyono. (2014). The effect of administrative sanctions, tax socialization and awareness of taxpayers on compliance with the submission of annual SPT for individual taxpayers (study at the Pratama Singosari Tax Office, Malang Regency). E-Taxation Journal, 1(1), 1-10.

Putri, Christella Pradista Riyana. (2015). Analysis of the Influence of Taxpayer Awareness, Tax Knowledge, Tax Information Dissemination and Fiscal Services on Taxable Obligations in Budget Hotels in Yogyakarta City. Journal of Atma Jaya University Yogyakarta.

Rajif, M. (2012). Effect of understanding, service quality, firmness of tax sanctions on tax compliance of SME entrepreneurs in the Cirebon area. Thesis. Gunadarma University

Risnawati. (2009). Effect of quality service tax on personal income taxpayer compliance. Journal of Economics and Informatics.

Rohmawati, A. N., \& Rasmini, A. N. (2012). Effect of awareness, counseling, services and tax sanctions on individual taxpayer compliance. Accounting E-Journal, 1(2), 1-17.

Sandi, N. B. (2010). Analysis of the influence of service, consulting, account representative supervision of taxpayer compliance. Thesis. Syarif Hidayahtullah State Islamic University.

Santoso, S. N., Susilo, H., \& Sulasmiyati, S. (2015). Effect of tax knowledge, taxpayer awareness, and tax sanctions on taxpayer compliance (study on individual taxpayers at the Kepanjen Primary Tax Office). Journal of Business Administration - Taxation (JAB), 6(1).

Savitri, E., \& Musfialdy. (2016). The Effect of Taxpayer Awareness, Tax Socialization, Tax Penalties, Compliance Cost at Taxpayer Compliance with Service Quality as Mediating Variable. Procedia - Social and Behavioral Sciences, 219, 682-687.

Septarini, Diana Fitri. (2015). The Influence of Services, Sanctions, and Taxpayer Awareness of the Compliance of Individual Taxpayers at the KPP Pratama Merauke. Journal of Economic \& Social Sciences, Volume VI NO. 1, APRIL 2015.

Sudrajat, A., \& Ompusunggu, A. P. (2015). Use of information technology, tax socialization, taxation knowledge, and tax compliance. Accounting and Taxation Research Journal, 2(2), 193-202.

Supriyati. (2012). Impact of taxation motivation and knowledge on taxpayer compliance. InFestation Journal, 8(1), 15-32. 
Tiraada, T. A. M. (2013). Awareness of taxation, tax sanctions, attitudes of tax authorities towards WPOP compliance in South Minahasa Regency. EMBA Journal, 1(3), 9991008.

Ulfa, Istika Herliani. (2015). The Influence of Awareness, Tax Knowledge and Taxpayer's Attitudes on Compliance with Free-Tax Payers in Kpp Pratama, East Semarang. Accounting journal. Dian Nuswantoro University.

Utami, T. D., \& Kardinal. (2013). Effect of taxpayer awareness and tax sanctions on individual taxpayer compliance at the Crossing Ulu KPP. Thesis. STIE MDP.

Widorini, S. G., \& Nugroho, J. P. (2014). Effect of knowledge, perceptions of tax rates and tax law enforcement on individual taxpayer compliance at KPP Pratama Yogyakarta. Efectif Journal of Business and Economics, 5(1), 85-98.

Widyastuti, E. (2015). The influence of the level of understanding of taxpayers, service quality, tax sanctions and tax environment on the level of individual taxpayer compliance (empirical study on KPP Pratama Solo). Thesis. Muhamadiyah University Surakarta. 